\title{
O mito moderno de François Villon e a origem do argot antigo
}

Daniel Padilha Pacheco da Costa ${ }^{a}$

\begin{abstract}
Resumo
Neste artigo, procura-se reconstituir a origem do argot antigo, definido pela linguística diacrônica do início do século XX como uma variedade socioletal de caráter convencional e secreto. Essa definição se baseia, sobretudo, na descrição por um documento jurídico medieval do jargão falado por uma quadrilha criminosa chamada os Coquillards. Por outro lado, essa definição foi utilizada para interpretar a mais importante composição do período a explorar literariamente esse jargão - as Baladas em jargão, atribuídas ao célebre malfeitor da época François Villon (1431-?). Pretende-se mostrar que a origem do argot antigo é indissociável do mito moderno sobre François Villon, considerado por seus editores e tradutores como o suposto autor empírico dessas baladas.
\end{abstract}

Palavras-chave: François Villon. Baladas em jargão. Argot antigo. Jargão dos criminosos. 


\section{Introdução}

Desde o surgimento da linguística moderna, o estudo diacrônico da língua tem se baseado em corpora literários transmitidos por suportes escritos. Até meados do século XX, esse estudo foi orientado, sobretudo, por critérios gramaticais fundados na assim chamada norma culta, em detrimento de diferentes variedades dialetais, socioletais e idioletais. Nesse sentido, foi priorizado o estudo de corpora que, pertencentes a gêneros graves do cânone literário de cada período histórico, faziam uso de registros linguísticos e estilísticos considerados mais elevados, segundo o decoro estabelecido pela retórica antiga. Ferdinand de Saussure, por exemplo, debruçou-se não apenas sobre as lendas germânicas medievais, mas também sobre os anagramas em diversos poetas greco-romanos, renascentistas e modernos.

Na primeira metade do século $X X$, surge o conceito de "língua popular", que, de acordo com uma distinção de classe social, opõe-se à norma culta. O estudo diacrônico da língua popular reproduziu os mesmos procedimentos utilizados para o da norma culta, colocando em evidência a ambiguidade da sua definição que, segundo Bruneau (1957, p. 240), pode ser entendida tanto de um ponto de vista linguístico quanto literário: o primeiro designa a variedade popular efetivamente falada por um determinado grupo social, enquanto o segundo define o uso dessa língua por escritores, a fim de produzir verossimilhança no discurso de personagens baixos. Essa ambiguidade é particularmente observável no estudo de uma importante variedade popular do francês chamada de argot.

Neste artigo, pretende-se estudar a origem dessa variedade, nomeada como jargão (jargon) pelos documentos transmitidos desde a Idade Média e batizada de argot antigo (argot ancien) pelos linguistas da primeira metade do século XX. Pelo seu caráter essencialmente oral, o jargão se perdeu, mas foi registrado por uma das primeiras composições poéticas a explorar essa variedade popular literariamente: as Baladas em jargão (Ballades en jargon), atribuídas ao célebre malfeitor da época François Villon (1431-?). Por faltar à recepção atual o conhecimento do jargão, essas baladas foram consideradas como um documento histórico capaz de oferecer, em primeira mão por um de seus integrantes, a língua secreta falada pela quadrilha criminosa dos assim chamados Coquillards. 


\section{O mito moderno de François Villon}

Desde a primeira edição do corpus atribuído a François Villon por Pierre Levet, intitulada Le grant testament Villon et le petit, son codicile, le jargon et ses balades (1489), foram publicadas, em anexo, seis baladas compostas num jargão obscuro da época falado pela quadrilha criminosa dos Coquillards. Essas baladas foram chamadas de Baladas em jargão. Essas seis baladas formam, junto com dois poemas longos em forma de testamento e uma dezena de baladas esparsas compostas em francês corrente, as CEuvres complètes de François Villon. As Baladas em jargão foram impressas com esse mesmo corpus aproximadamente vinte vezes até a primeira metade do século XVI (DOP-MILLER, 1991, p. 217). Mas todas essas edições são póstumas, nenhuma foi autorizada pelo seu autor empírico.

No final do século XIX, foi descoberto no manuscrito de Estocolmo, que constitui um dos quatro principais manuscritos contendo as suas obras, outras cinco Baladas em jargão. Esse manuscrito, datado de 1477, é anterior à edição Levet (VILLON, 2014, p. 819). Essas cinco baladas foram publicadas pela primeira vez no final do século XIX em Le jargon du XVème siècle, étude philologique: onze ballades en jargon attribués à François Villon, dont cinq ballades inédites (1883), de Auguste Vitu. À diferença das dezenas de variantes das seis baladas da edição Levet, há uma única versão dessas cinco baladas no manuscrito de Estocolmo. Esse manuscrito é apógrafo, como todos os manuscritos de Villon (VILLON, 1923, p. 152). ${ }^{1}$

O linguista Pierre Guiraud realizou a última tradução especializada das Baladas em jargão. Os seus estudos sobre Villon foram determinantes para a "guinada linguística" proposta pela nova crítica da França que, sob a influência da "morte do autor" do final dos anos 1960, deslocou o interesse da biografia para a construção ficcional da persona poética (COSTA, 2014, p. 77). Guiraud foi o primeiro crítico a ter chamado a atenção para o anonimato do corpus das Baladas em jargão. Diversos documentos jurídicos da segunda metade do século XV mencionam o célebre malfeitor da época "François des Loges, também chamado de Villon" (LONGNON, 1877, p.

1 "Ignora-se qualquer manuscrito autógrafo de Villon" (tradução nossa). 137). Embora a persona poética das composições se baseie nesse indivíduo histórico, nada permite determinar que este último tenha, efetivamente, sido o autor empírico daquele corpus. 
Mas Guiraud não foi muito bem recebido pela crítica da época, apesar da novidade oferecida por sua leitura e tradução daquelas obscuras baladas atribuídas a Villon. Um dos principais representantes da crítica biografista, o filólogo italiano Ítalo Siciliano, ridicularizou as suas "extravagâncias filológicas" (SICILIANO, 1973, p. 63). Desse modo, Guiraud permanece sendo o único crítico a ter questionado o pressuposto essencial partilhado por todos os editores e tradutores modernos, segundo o qual o autor empírico daquele corpus teria sido o célebre malfeitor François Villon (GUIRAUD, 1968, p. 303). Ainda que coloque em dúvida a autoria das Baladas em jargão pelo assim chamado "Villon histórico", Guiraud não prescinde do conceito de "autobiografia" para analisar as Baladas em jargão.

Ele diverge apenas do reducionismo do método biografista, considerando os poemas não como uma autobiografia "sincera", mas ficcional. Portanto, a análise biografista deve ser completada pela exegese linguística, já que a vida do célebre malfeitor serve apenas como ponto de partida para a criação da sua "ficção autobiográfica". Com efeito, qualquer escritor da época poderia ter se baseado em elementos verdadeiros ou verossímeis da vida do célebre malfeitor da época chamado François des Loges para compor a sua personagem ficcional. Para Guiraud, não há dúvidas de que esse indivíduo tenha integrado a quadrilha dos Coquillards: “Quant à Villon, les ballades [en jargon] laissent peu de doute sur son appartenance à la bande" (GUIRAUD, 1968, p. 9). ${ }^{2}$

Mas nenhum documento histórico da época associa o indivíduo François des Loges à célebre quadrilha dos Coquillards; nem mesmo o Procès des Coquillards, que constitui um documento jurídico sobre a quadrilha. O Procès possui uma longa lista de nomes próprios de diversos integrantes da quadrilha que tinham sido presos, torturados e enforcados pelo poder real, mas o nome de Villon não aparece nessa lista (SAINÉAN, 1912, p. 98). Embora Guiraud a considere como evidente, a hipótese de que aquele célebre malfeitor tenha

2 "Quanto a Villon, as baladas [em jargão] deixam poucas dúvidas quanto ao seu pertencimento à quadrilha" (tradução nossa). pertencido à quadrilha dos Coquillards não é estabelecida por nenhum elemento histórico. Essa hipótese se baseia apenas em elementos textuais do próprio corpus, como a representação pelas Baladas em jargão da personagem de um Coquillart e o acróstico em uma dessas baladas contendo o nome de "villon". 
Em primeiro lugar, há um vínculo temático indissociável entre Baladas em jargão e a subseção do Testament intitulada “Belle leçon aux enfants perdus" (VILLON, 2014, p. 142). Aquelas constituem um desenvolvimento considerável dessa subseção, pois ambas foram compostas no gênero do sermão jocoso, imitando a peroração dos sermões da época em que se exortava à virtude. Nelas, a personagem do vilão arrependido no papel de pregador exorta em gênero grave os comparsas a abandonarem as suas atividades criminosas antes de serem capturados e enforcados pelo poder real. Diferentemente daquela subseção do Testament, no entanto, as Baladas em jargão foram inteiramente compostas no jargão utilizado pela célebre quadrilha dos Coquillards, o que atribui a esse destinatário preciso o sermão ficcional enunciado pela personagem do célebre malfeitor.

Em segundo lugar, uma das baladas em jargão pertencente ao manuscrito de Estocolmo contém o nome "villon" em acróstico. ${ }^{3}$ Esse procedimento, que é produzido pelas letras iniciais de cada verso, pode ser encontrado em três baladas anônimas da época - a Ballade des contreverités, a Ballade de bon conseil e o Débat du cour et du corps de Villon. Essas três baladas foram atribuídas a Villon pela maioria dos seus editores modernos. $\mathrm{O}$ mesmo critério também foi utilizado para atribuir a balada em jargão contendo o nome "villon" em acróstico como autêntica. Embora considere as baladas do manuscrito de Estocolmo como inautênticas, Sainéan reconhece que a balada com um acróstico seja autêntica (SAINÉAN, 1912, p. 117). Assim, ele considerou as outras quatro baladas em jargão como "imitações no estilo de Molinet" (SAINÉAN, 1912, p. 121).

Sainéan considerou autênticas sete Baladas em jargão as seis da edição Levet e a Balada em jargão do manuscrito de Estocolmo contendo "villon" em acróstico. Outros editores, como a medievalista Jacqueline Cerquiglini-Toulet (VILLON, 2014, p. 821), consideraram as onze baladas autênticas.

3 "Vive David, saint archquin la baboue/ Iehan mon amy qui les fueilles desnoue/ Le vendengeur beffleur comme une choue/ LOing de son plain de ses flos curieulx/ Noe beaucoup dont il reçoit fressoue" (SAINÉAN, 1912, p. 127). Guiraud baseou-se no critério editorial segundo o qual, na falta de um manuscrito autógrafo, a edição mais antiga deve ser considerada como a única "autorizada" (GUIRAUD, 1968, p. 307). Ele elegeu como autênticas apenas as seis baladas publicadas pela primeira vez pela edição Levet, lançando sobre as cinco baladas do manuscrito de Estocolmo fortes suspeitas de inautenticidade. A querela persiste, e as seis baladas da 
edição Levet permanecem sendo as únicas consensualmente consideradas por todos os seus editores e tradutores como autênticas.

A maior parte dos editores modernos de Villon publicou as seis Baladas em jargão da edição Levet juntamente com as suas obras. Mas a mais importante edição recente de Villon, realizada por Rychner e Henry, exclui as Baladas em jargão das suas obras. As traduções das CEuvres complètes de François Villon em francês moderno são destinadas não a um público especializado, mas a um público mais amplo interessado pelo poeta. Pela antiguidade do francês da época, elas visam oferecer um apoio para a leitura do texto original. Mas as Ballades en jargon sequer podem ser compreendidas por leitores habituados ao francês médio, por causa da obscuridade do jargão. Há dez traduções dessas baladas em francês moderno: três estão incluídas em edições das CEuvres complètes de François Villon e sete em edições exclusivas dessas baladas.

No primeiro grupo, as edições realizadas por Jean-Claude Mühlethaler (2004) e por Jacqueline Cerquiglini-Toulet (2014) incluem as onze Baladas em jargão, enquanto a tradução de Jean Dufournet (1992) inclui apenas seis. No caso da edição Mühlethaler, a tradução daquelas baladas foi deixada aos cuidados de Érick Hicks. No segundo grupo, Pierre d'Alheim, Armand Ziwès e Pierre Guiraud traduziram as seis da edição Levet, Lucien Schöne também incluiu a balada com acróstico do manuscrito de Estocolmo e Auguste Vitu ocupou-se das onze. As mais recentes traduções exclusivas das Baladas em jargão foram realizadas por André Lanly (1971) e Ionela Manolesco (1980). Esta última inclui apenas quatro baladas, enquanto a tradução de André Lanly inclui as onze.

À exceção do linguista Pierre Guiraud, todos os editores modernos e tradutores das Baladas em jargão consideraram o "Villon histórico" como o autor daquele corpus, segundo a concepção moderna de autor como indivíduo empírico e garantia da autenticidade da obra. Mas não há qualquer evidência histórica que permita comprovar essa atribuição, considerada como autoevidente. Com efeito, o único manuscrito dessas baladas é apógrafo, não autógrafo (escrito do punho do próprio autor). Igualmente, todas as suas edições são póstumas, inexistindo qualquer edição autorizada. Portanto, os editores modernos e tradutores das Baladas em jargão confundiram o seu 
autor empírico com a personagem ficcional de um Coquillart, que é assumida nas composições.

\section{A origem do argot antigo}

Em seu célebre estudo Les sources de l'argot ancien (1912), publicado há pouco mais de um século, Lazare Sainéan procurou reconstituir a origem do argot antigo. Ele descobriu uma língua chamada de "jargão" (jargon) por documentos da segunda metade do século XV. Assim como em português, o termo "jargão" designa, em francês, um vocabulário especializado próprio a uma determinada corporação. Ao sofrer uma "reforma" no século XVII, o jargão foi dicionarizado e passou a ser designado como "argot", como testemunha o Jargon de l'argot reformé (1628). O jargão é definido por Sainéan como uma língua secreta falada na França por uma célebre quadrilha criminosa. Essa definição se baseia, sobretudo, na descrição do jargão presente num documento jurídico de meados do século XV intitulado o Procès des Coquillards (1455).

Esse documento constitui as atas do processo de acusação realizado na cidade de Dijon contra a quadrilha. No Procès, a descrição do jargão falado pelos Coquillards foi realizada não apenas por alguns de seus integrantes, mas também por agentes do poder real, infiltrados no grupo. As provas reunidas no processo permitiram condenar e punir seus membros, desbaratando completamente a quadrilha. A língua falada pela quadrilha criminosa possui uma dimensão identitária, pois é uma das principais características daquele subgrupo social. A identidade da quadrilha é negativamente caracterizada do ponto de vista moral, por ser constituída exclusivamente por indivíduos maus: "Et telz langaiges par lesquelz il povoit bien entendre qu'ilz estoient malvaiz garnements" (SAINÉAN, 1912, p. 103). ${ }^{4}$

Da mesma forma, a identidade linguística do grupo também é definida negativamente pelo jeito de falar confuso do jargon, cuja etimologia é originada a partir do som emitido pelo gorjeio dos pássaros. Graças a esse jeito de falar, eles são

4 "E por meio dessas línguas eles podiam se reconhecer uns aos outros como maus indivíduos" (tradução nossa). capazes de se reconhecer entre si, sempre que encontram uns aos outros. Ojargão da quadrilha é assim definido: "Et est vray, comm'il dit, que lesdiz. Coquillars ont entr'eulx un langaige exquiz que aultres gens ne scevent entendre, s'ilz ne l'ont 
5 “E, como ele disse, é verdade que os referidos Coquillards possuem entre si uma linguagem estranha, que outras pessoas não sabem compreender, se eles não lhes revelaram nem ensinaram" (tradução nossa).

6 "Um beaul soyant é um bom falador, que tem boa linguagem e que sabe enganar a justiça ou outras pessoas com boas estórias. Ferme en la mauhe é aquele que evita muito bem confessar qualquer coisa à justiça, etc. [quando ele é preso e interrogado]" (tradução nossa). revelez et aprins: par lequel langaige ilz congnoissent ceulx qui sont de lad" (SAINÉAN, 1912, p. 91). ${ }^{5}$ A expressão "língua estranha" é utilizada no francês da época para designar os falantes de uma língua estrangeira. $\mathrm{O}$ uso do jargão permite selecionar o receptor, pois o seu caráter secreto exclui da comunicação todos aqueles que o desconhecem.

Assim, essa língua é utilizada como estratégia de proteção pelos membros da quadrilha, pois quando eles falam no seu jargão, é porque surge alguém que lhes possa prejudicar. Essa língua só pode ser aprendida por meio do convívio com os integrantes da quadrilha. Há um acordo tácito entre esses integrantes, que lhes proíbe de ensinar o jargão a qualquer um que não pertença ao grupo. $O$ fato de falar em jargão também permite aos agentes infiltrados do poder identificar os membros da quadrilha. Mas essa identificação é negativa, já que é a incompreensão do que eles falam que permite reconhecê-los. O membro dos Coquillards que está encarregado de vigiar a chegada de estranhos utiliza a estratégia de cuspir no chão para indicar aos comparsas que estes devem se calar e mudar de assunto, antes que estranhos os reconheçam (SAINÉAN, 1912, p. 105).

O jargão não é a única estratégia para esconder o sentido da troca linguística entre os membros da quadrilha. Os Coquillards também utilizam a língua comum para enganar os membros da justiça, quando são capturados. Esse uso sempre envolve a mentira, como mostram as seguintes expressões enumeradas no Procès: “Ung beaul soyant c'est ung beaul parleur, bien enlangaigié, qui scet decepvoir justice ou aultres gens par belles bourdes. Ferme en la mauhe c'est celluy qui se garde bien de confesser riens a justice etc. [lorsqu'il est prins et interrogué]" (SAINÉAN, 1912, p. 98). ${ }^{6}$ Assim, os Coquillards possuem uma maneira de dissimular o sentido quando falam o jargão e outra quando utilizam a própria língua corrente, mas a função das duas é a mesma: a proteção do grupo.

Sainéan introduziu o Procès des Coquillards na primeira parte do seu estudo, intitulada "documentos jargonescos". Na segunda parte, intitulada "documentos literários", ele inseriu as utilizações literárias do argot antigo por diferentes gêneros ficcionais na França desde a segunda metade do século XV até o início do século XX. Aproximadamente na mesma época das Baladas em jargão, o jargão foi imitado por um significativo 
número de composições, em particular pelos chamados "mistérios" (mysterès), que constituíam um gênero dramático da vasta literatura hagiográfica produzida na Idade Média. A presença do jargão nos mistérios do século XV foi considerada por Sainéan como uma representação realista de "traços dos costumes da época" (SAINÉAN, 1912, p. 265).

Nos mistérios, o léxico próprio do jargão aparece em diálogos burlescos para caracterizar o discurso de personagens baixas, como o vilão, o carrasco, o mendigo e o charlatão. No terceiro livro do Mystère des actes des apôtres, ele é utilizado no diálogo entre "mendigos" (belistres). O jargão é utilizado em assembleias de carrascos presentes no Mystère de la passion e no Mystère de la vie de saint Christophle. No diálogo entre quatro carrascos deste último mistério, cada carrasco fala no seu jargão de origem (picardo, gascão, suíço-germano e lombardo). Um dos últimos mistérios a explorar literariamente o jargão, o Mystère de la vie de saint Christophle imita inteiramente o jargão utilizado nas Baladas em jargão: "La vie de saint Christophle (1530) du maître Chevallet a puisé presque tout son savoir jargonnesque dans le jobelin de Villon" (SAINÉAN, 1912, p. 23).

Na Farce de Pierre Pathelin (1986), o mesmo procedimento é explorado para produzir um efeito cômico. Na quinta cena, o comerciante de tecidos vai até a casa do advogado Pathelin para cobrar os tecidos que este levara de manhã de sua loja, mas Pathelin finge estar doente. Ao receber o comerciante, a sua esposa Guillemette confirma a mentira de que o marido está, há onze semanas, de cama. Enquanto ela discute com o comerciante, o advogado charlatão finge delirar em voz alta; depois de falar coisas desconexas, ele começa a pronunciar palavras oriundas de línguas estrangeiras, como uma língua que se falava em Limoges, uma língua dos romanos antigos, outra de Flandres e uma quarta da Bretanha. Com a intenção de persuadir o vendedor de que está delirando, o discurso obscuro da personagem visa ludibriar o vendedor.

Esse procedimento estilístico continuou sendo explorado ao longo do século XX, como, por exemplo, em Le Feu (1920), de Henri Barbusse. Embora não tenha sido estudado por

7 "A vida de São Cristóvão (1530) do Mestre Chevallet recolheu quase todo o seu saber jargonesco no jobelin de Villon" (tradução nossa). Sainéan - já que o seu primeiro romance, Le voyage au bout de la nuit, foi publicado em 1932 -, um dos principais escritores contemporâneos a explorarem literariamente o argot foi o romancista Louis-Ferdinand Céline (1894-1961). Os seus 
romances refletem a preocupação estilística fundamental de transmitir na escrita a carga emocional da linguagem falada, rompendo com a rigorosa sintaxe da língua francesa por meio de uma pontuação marcada por reticências. Assim, Céline não busca mimetizar servilmente a coloquialidade da linguagem oral, mas, pelo contrário, produzir na própria escrita um efeito de oralidade ao qual chama de "rendu émotif" (CÉLINE, 1955).

Assim, o corpus de textos recolhido por Sainéan para estudar o argot é essencialmente literário, reconstituindo apenas de forma indireta a citação feita pelos escritores do argot falado por diferentes variedades socioletais, dialetais e idioletais. Enquanto fontes literárias, esses textos não reproduzem essas variedades enquanto tais, mas apenas utilizam elementos lexicais oriundos delas para caracterizar personagens baixos. Da mesma forma que as demais composições literárias, as Baladas em jargão exploram o jargão dos Coquillards para conferir verossimilhança à representação literária da personagem ficcional do célebre malfeitor da época François Villon. Mas elas não foram introduzidas por Sainéan na segunda parte de seu estudo sobre a origem do argot antigo, dedicada aos "documentos literários", mas na primeira parte, dedicada aos "documentos jargonescos".

Ao contrário de todas as outras composições literárias que utilizaram o jargão, as Baladas em jargão também foram consideradas como um documento histórico do jargão falado pela quadrilha, da mesma forma que o Procès des Coquillards. Sainéan supôs não apenas que o célebre malfeitor da época François Villon tivesse sido um integrante daquela quadrilha criminosa, mas, sobretudo, que ele fosse o autor empírico daquelas baladas: "Pour les avoir fréquentés, ou avoir vécu comme eux, François Villon entendit le langage des Coquillards et s'amusa à composer en leur jargon" (SAINÉAN, 1912, p. 422) . As Baladas em jargão foram consideradas como um documento histórico capaz de oferecer a língua falada pela quadrilha dos Coquillards em primeira mão por um de seus integrantes.

Desse ponto de vista, elas seriam um registro verídico

8 "Por lhes ter frequentado, ou vivido como eles, François Villon ouviu a linguagem dos Coquillards e se divertiu ao escrever em seu jargão" (tradução livre do editor). feito por um criminoso, não composições ficcionais inventadas por um poeta. $\mathrm{O}$ acesso ao jargão por meio dessas baladas pressupôs que elas oferecessem um reflexo fiel do suposto jargão falado pelos Coquillards: "Si nous examinons maintenant les rapports de ces morceaux avec le jargon des Coquillards, 
9 "Se examinamos agora as relações dessas peças com o jargão dos Coquillards, podemos afirmar que elas são da mesma língua que François Villon se esforçou em falar" (tradução nossa).

10 “Uma linguagem especial que permanece intencionalmente secreta, ou que forja, todas as vezes que a necessidade a obriga, palavras e frases intencionalmente mantidas na sombra, pois o seu objetivo consiste essencialmente na proteção do grupo de malfeitores" (tradução nossa).

11 "Mas, se havia uma língua do povo, tudo postula que ela era também a língua dos criminosos - a sua língua de uso; e que, além dela, eles possuíam uma língua secreta e parasitária - o jargão" (tradução nossa). nous pouvons affirmer qu'ils sont de cette même langue que François Villon s'efforça de parler" (SAINÉAN, 1912, p. 120). ${ }^{9}$ As Baladas em jargão foram uma das primeiras composições literárias a empregarem o jargão secreto falado pelos Coquillards. Como teriam sido compostas por um dos supostos integrantes dessa quadrilha, elas foram consideradas como a principal fonte para o estudo do jargão.

\section{O segredo das Baladas em jargão}

De um ponto de vista histórico, o jargão foi considerado por Sainéan como a fonte principal para o estudo do argot antigo. Esse termo, cunhado pelo linguista, permitiu-lhe distinguir entre o argot antigo e o moderno. Este último confunde-se, em particular, com a língua popular francesa falada em Paris no início do século XX, enquanto o argot antigo é definido pelo seu caráter convencional e secreto (SAINÉAN, 1912, p. 12). Essa definição do argot antigo baseia-se em diversas características do jargão descritas no Procès des Coquillards. O argot moderno também é definido como uma variedade socioletal falada por determinadas categorias populares, mas essas deixam de ser negativamente caracterizadas do ponto de vista moral, como a quadrilha dos Coquillards.

Desde o início do século $X X$, foi produzido significativo número de estudos linguísticos sobre o argot. Esses estudos retomam, em grande medida, a definição de Sainéan, segundo a qual ele constitui uma variedade socioletal, cuja origem histórica reside no jargão dos Coquillards. De um modo geral, os linguistas definiram o argot como uma variedade socioletal de caráter secreto e convencional, originalmente falada por uma quadrilha de malfeitores formada, principalmente, por ex-soldados da guerra dos cem anos (BECKER-HO, 1992). Da mesma forma que a definição do jargão presente no Procès, essa variedade socioletal devia permanecer secreta, a fim de garantir a "proteção do grupo de malfeitores", como afirma Alfredo Niceforo em Le génie de l'argot (NICEFORO, 1912, p. 10). ${ }^{10}$

Em seu livro dedicado ao argot, Pierre Guiraud define essa língua especial dos malfeitores como uma "língua segunda" (seconde langue) que, parasitária da língua popular, sempre foi parte constitutiva dela (GUIRAUD, 1956, p. 17). ${ }^{11}$ Esse conceito define o caráter artificial do argot, ao contrário da língua 
12 “Nós encontramos nelas [nas Baladas em jargão] as mesmas palavras, incrustadas com mais ou menos felicidade, em construções francesas: pois o jargão jamais foi uma língua" (tradução nossa).

${ }^{13} \mathrm{Na}$ primeira Balada em jargão, aparecem os termos plantes, duppes, bleffleurs, vendengeurs, ances, sires, arques. $\mathrm{Na}$ segunda, aparecem os termos Coquillars, roe, jarte, piperie; na terceira, aparecem os termos longs, caire; na quinta, aparecem os termos quilles, blanchir, roupieux; e na sexta, aparece o termo feuilles.

14 "As palavras do jargão não existem em francês (a menos que elas tenham entrado posteriormente na língua, como dupe, niais etc.); no entanto, elas se ligam diretamente ao francês por processos determinados de derivação morfológica e semântica (e, frequentemente, as duas juntas)" (tradução nossa).

15 “Um long é um homem que é bem sutil em todas as especialidades ou em algumas delas" (SAINEAN, 1912, p. 95, tradução nossa).

16 "Um vendangeur é um batedor de carteiras ou bolsas" (SAINÉAN, 1912, p. 95, tradução nossa). popular que, chamada de "francês médio" (moyen français), era aprendida desde o nascimento. Essa definição não deixa de lembrar a comparação, apresentada no Procès, entre o jargão e uma língua estrangeira. Enquanto língua segunda, o argot é indissociável da língua popular, de onde retiraria não apenas a maior parte do seu léxico, mas, sobretudo, as suas próprias estruturas sintáticas.

Com base em sua definição do argot antigo, Sainéan já reduzira o jargão utilizado nas Baladas em jargão a um léxico especializado incrustado em construções sintáticas do francês corrente: "On y retrouve les mêmes mots, enchâssés avec plus ou moins de bonheur, dans des constructions françaises: car le jargon n'a jamais été une langue" (SAINÉAN, 1912, p. 120). ${ }^{12}$ A identificação, por parte dos linguistas do argot, do jargão utilizado nas Baladas em jargão àquele falado pelos Coquillards vinculou a compreensão daquelas baladas à decifração dessa língua. Como se verifica na lista de palavras do jargão presente no Procès, as Baladas em jargão de fato se apropriam de palavras utilizadas pela quadrilha. As seis baladas da edição Levet contam dezessete termos citados no Procès que, sem dúvida, são oriundos do jargão dos Coquillards. ${ }^{13}$

Além disso, o conjunto das onze Baladas em jargão também inclui dezenas de outros termos obscuros provavelmente pertencentes àquele jargão. O léxico especializado utilizado nessas composições designa, em particular, as suas práticas criminosas, como o roubo, a fraude, a extorsão, a falsificação de dinheiro e a trapaça. Com base nas "leis de derivação semântica e morfológica", Guiraud procurou reconstituir as palavras da língua popular a partir das quais as formas do jargão foram semântica e formalmente derivadas: “Les mots de jargon n'existent pas en français; [...] toutefois, ils se rattachent directement au français par des procédés déterminés de dérivation morphologique ou sémantique (et souvent les deux combinés)" (GUIRAUD, 1968, p. 20). ${ }^{14}$

O significante das palavras do jargão sempre se vincula ao de algum termo da língua popular. Um "anjo" (ange) designa ironicamente no jargão o agente do poder real. A substantivação de um "longo" (long) designa um homem habilidoso em todo tipo de golpe (SAINÉAN, 1912, p. 96). ${ }^{15}$ Os chamados vendangeurs designam, em francês, quem colhe uvas e, no jargão, os batedores de carteiras ou bolsas. ${ }^{16}$ Há diversos 
17 “Um homem simplório que não conhece as suas habilidades é um sire, ou um duppe, ou um blanc" (SAINEAN, 1912, p. 97, tradução nossa).

18“Umbeffleuréumladrão que atrai companheiros simplórios para jogar" (SAINÉAN, 1912, p. 95, tradução nossa).

19 "Estamos longe das Baladas em jargãa, daqueles repertórios monstruosos cujo sentido e função é ser impenetrável" (tradução nossa).

20 "Os jogos da Morte, do Jogo e do Amor" (tradução nossa). termos para designar a vítima dos seus crimes, como "senhor" (sire), "branco" (blanc) ou "tolo" (duppe)..$^{17}$ Metáforas produzidas a partir de jogos de carta também são comuns, como "blefador" (beffleur), que designa quem trapaceia no jogo de cartas. ${ }^{18}$ Outros termos são decalques de palavras do registro corrente, como Parouart, que constituiria uma sufixação de "Paris".

Assim, as palavras do jargão sempre possuem um sentido secreto que, no mais das vezes, é derivado da figuração do sentido do termo corrente. Dada a dificuldade de compreender o sentido secreto desse léxico especializado, as suas primeiras traduções foram todas realizadas por especialistas do argot. As primeiras traduções apareceram ainda no século XIX: primeiro a de Lucien Schöne (1888) e, em seguida, as de Auguste Vitu (1889) e Pierre d'Alheim (1892). A partir de meados do século XX foram feitas mais duas traduções, por Armand Ziwès (1954) e Pierre Guiraud (1968). Essas cinco traduções, realizadas por linguistas do argot, oferecem longos comentários sobre os termos do jargão. A partir dessas cinco traduções especializadas das Baladas em jargão, os medievalistas e críticos do poeta realizaram as traduções mais recentes.

A própria definição do argot como um léxico secreto foi determinante para a interpretação do sentido das Baladas em jargão. Segundo a interpretação pressuposta por todos esses tradutores, François Villon teria utilizado as palavras do jargão para criar um nível secreto de significação. Desse ponto de vista, o jargão utilizado nas Baladas em jargão selecionaria o receptor nomeado internamente, comunicando-se tão somente com os comparsas do poeta. Em La poétique de François Villon (1967), David Kuhn considera que a opacidade semântica do jargão desempenha uma função estilística essencial. A obscuridade do jargão impediria que o público de burgueses da época o compreendesse, estabelecendo uma distância intransponível entre o público e a mensagem, como afirma Kuhn (1967, p. 450). ${ }^{19}$

Para Pierre Guiraud (1968, p. 25), as Baladas em jargão constituem um código fechado, cuja "chave" acredita ter encontrado no dialeto bourguignon da época. O linguista não reduz as baladas a um único nível secreto, mas descobre três níveis de significação, intitulados respectivamente: "Jeux de la Mort, des Cartes et de l'Amour" (GUIRAUD, 1968, p. 7). ${ }^{20}$ Nesse sentido, o primeiro nível secreto trataria das práticas 
criminosas da quadrilha, o segundo seria relativo ao jogo de cartas e o terceiro se referiria ao "amor pederástico" praticado pelos malfeitores nas prisões. Por trás das alusões às práticas criminosas da quadrilha e ao jogo de cartas, ele considera como o nível mais secreto de significação dessas baladas a sua profusão de alusões homoeróticas.

Assim, Guiraud propõe não apenas uma, mas três traduções de cada balada, isto é, uma "três-dução" (troisduction), totalizando dezoito traduções das seis Baladas em jargão da edição Levet. Como mensagem composta no jargão secreto da quadrilha dos Coquillards, essas baladas retomariam o gênero da lírica cortês medieval chamado de "trovar fechado" (trobar clus), como afirma Guiraud (1968, p. 8). ${ }^{21}$ Compostas sob a forma de uma alegoria fechada ou enigma, essas baladas retomariam a figuração extrema das canções mais enigmáticas compostas pelos trovadores provençais. Mas independentemente do número de níveis secretos, todos os filólogos interpretaram as Baladas em jargão como um texto que deve ser "decifrado" com base na compreensão da língua secreta dos Coquillards.

Independentemente de possuírem um ou mais sentidos secretos, está na base de todas essas interpretações e traduções que as Baladas em jargão são essencialmente crípticas. Desse ponto de vista, o uso do jargão constituiria uma estratégia de defesa utilizada pelo poeta para advertir sub-repticiamente os comparsas do perigo de serem presos, torturados e enfocados. Segundo essa interpretação biográfica, a situação de enunciação concreta dessas composições pressuporia a perseguição então em curso à quadrilha dos Coquillards. As Baladas em jargão seriam basicamente um aviso aos companheiros para que eles abandonassem as suas atividades criminosas e fugissem dos agentes do poder real, antes de receberem a punição que, de fato, sobreveio à maior parte deles, como testemunha o Procès des Coquillards.

21 "[...] um exemplo - sem dúvida o único nesse grau de complexidade de trovar fechado. O texto é um breviário do gaio saber dos Coquillards" (tradução nossa).

\section{Conclusão}

A mistura entre o sentido literário e linguístico das Baladas em jargão deriva da ambiguidade do próprio vocabulário que, usado desde o final do século XIX para descrevê-las, confunde autor e personagem, língua e linguagem poética, e mensagem 
ficcional e comunicativa. Assim, o personagem assumido nas composições foi definido como o seu autor empírico; a linguagem poética utilizada pelo personagem foi tomada como língua falada pelo seu autor; e, por fim, a mensagem ficcional dos poemas foi identificada à mensagem secreta no jargão dos Coquillards. Ao distinguir o sentido próprio a cada um desses termos, pretendeu-se mostrar que a suposta origem do argot antigo é indissociável do mito moderno sobre o célebre malfeitor François Villon, considerado o suposto autor empírico das composições poéticas.

O exame da história da transmissão desse corpus por edições póstumas e um manuscrito apógrafo levantou a questão da unidade das Baladas em jargão atribuídas a Villon. Os seus editores e tradutores pretenderam unificá-las em torno do mesmo autor empírico pressuposto na origem da enunciação, mas a variação dos critérios de autenticidade só tornou explícita a precariedade da atribuição. A suposta unidade desse corpus jamais existiu, pois o seu suposto autor empírico não pode ser conhecido com base nas informações históricas atualmente disponíveis. Portanto, essa unidade é tão somente o resultado do trabalho realizado pelos seus editores, copistas e tradutores desde a sua primeira edição no final do século $X V$ até a sua última tradução no início do século XXI.

Da mesma forma que esse corpus não pode ser unificado em torno do seu suposto autor empírico, a interpretação das Baladas em jargão não pode ser reduzida ao sentido específico dos termos do jargão, que produziria uma mensagem secreta enviada pelo célebre malfeitor a seus comparsas Coquillards para avisar da perseguição em curso pelos agentes do poder real. A obsessiva preocupação dos críticos com o sentido secreto dos termos do jargão transformou essas baladas num inextrincável objeto de exegese linguística. Mas o questionamento do mito moderno de François Villon implode a própria unidade do sentido biografista que, exclusivamente baseado na decifração do argot antigo, imperou em todas as interpretações e traduções das Baladas em jargão. 


\section{REFERÊNCIAS}

BECKER-HO, A. Les princes du jargon: un facteur négligé aux origines de l'argot des classes dangereuses. Paris: Gallimard, 1992.

BRUNEAU, C. Langue populaire. Cahiers de l'association internationale des études francaises, 1957, n. 9, p. 238-249.

CÉLINE, L.-F. Entretiens avec le Professeur Y. Paris: Gallimard, 1955.

COSTA, D. P. P. Autor e personagem: François Villon e a nova crítica na França. Revista Criação e Crítica, São Paulo, n. 12, p. 76-87, 2014.

DOP-MILLER, C. Clément Marot et l'édition humaniste des Euvres de François Villon. Romania, Paris, n. 112, vol. 1-2, p. 217-242, 1991.

GUIRAUD, P. L'argot. Paris: Presses Universitaires de France, 1956. Le jargon de Villon, ou Le Gai savoir de la Coquille. Paris: Éditions Gallimard, 1968.

KUHN, D. La poétique de François Villon. Paris: Armand Colin, 1967.

LACASSAGNE, J. L'argot du 'milieu'. Paris: Albin Michel Éditeur, 1897.

MAISTRE Pierre Pathelin: farce du XV siècle. Édition par Richard T. Holbrook. Paris: Champion, 1986.

MANOLESCO, I. Quatre ballades de Villon en jargon traduites en français moderne. Études Françaises, vol. 16, n. 1, p. 71-107, 1980. NICEFORO, A. Le génie de l'argot. Paris: Mercure de France, 1912. SAINÉAN, L. Les sources de l'argot ancien. Paris: Honoré et Édouard Champion, 1912. v. I.

SCHÖNE, L. Le jargon et jobelin de François Villon, suivi du Théatre. Paris: Alphonse Lemerre, 1888.

SCHWOB, M. Le petit et le grant testament de François Villon, Les cinq ballades en jargon et des poésies du cercle de Villon. Paris: Honoré Champion, 1905.

. Le grant testament Villon et le petit, son codicile, le jargon et ses balades. Paris: Pierre Levet, 1489.

. Les Ballades en jargon de M. François Villon. Paris: PFL, 1949. 
Le jargon jobelin de maistre François Villon. Paris: Pierre d'Alheim e Albert Savine, 1892.

Le petit et le grant testament de François Villon, Les cinq ballades en jargon et des poésies du cercle de Villon etc. Reproduction facsimile du manuscrit de Stockholm avec une introduction de Marcel Schwob. Paris: Honoré Champion, 1905.

. CEuvres. Edition critique avec notices et glossaire. Édition par Louis Thuasne. Paris: Auguste Picard, 1923. . CEuvres complètes. Édition par Auguste Longnon et Lucien Foulet. Paris: Honoré Champion, 1932.

Le jargon et jobelin, comprenant cinq ballades inédites avec un Dictionnaire analytique du jargon. Édition par Auguste Vitu. Paris: Paul Ollendorff, 1889.

Ballades en jargon (y compris celles du manuscrit de Stockholm). Traduits par André Lanly. Paris: Librairie Honoré Champion, 1971.

Poésies. Édition et traduction par Jean Dufournet. Paris: GF-Flammarion, 1992.

Ballades en jargon. Traduction, présentation et notes par Éric Hicks. In: Lais, testament, poésies diverses. Traduction, présentation et notes par Jean-Claude Mühlethaler. Paris: Champion, 2004.

CEuvres complètes. Édition et traduction par Jacqueline Cerquiglini-Toulet. Paris: Gallimard, 2014.

ZIWÈS, A.; BERCY, A. Le jargon de maître François Villon. Paris: Marcel Puget, 1954. 


\section{Abstract \\ The modern myth of François Villon and the origin of ancient Argot}

This paper attempts to reconstruct the origin of the ancient Argot, defined by the diachronic linguistics of the early twentieth century as a conventional and secret sociolect. This definition is based, above all, on the description by a medieval legal document of the jargon spoken by a gang of criminals called the Coquillards. On the other hand, this definition was used to interpret the most important composition of the period to explore the jargon literarily - the Ballads in jargon, attributed to the well-known criminal of the time François Villon (1431-?). It is intended to show that the origin of the ancient Argot is inseparable from the modern myth about François Villon, considered by its editors and translators as the supposed empirical author of these ballads.

Keywords: François Villon. Ballads in jargon. Ancient Argot. Jargon of the criminals. 